the necropsy the cord showed less involvement than the brain. In other examples the cord appears to have been affected to an equal extent with the brain, but in this one there certainly was less pus in the thecal space and less softening of the tissue of the cord.

While the treatment by other means is so unsatisfactory, it seems reasonable to suggest that both urotropin and spinal lavage are worthy of further trial.

In conclusion, we desire to thank Dr. Eustace Smith for lindly permitting us to publish the notes of the case.

${ }^{1}$ Batten, Lancet, 1910, vol. i. p. 1677. ${ }^{2}$ Douglas. Rep. Clin. and Tesearch Lub. St. George's Hospital, 1910, pp. 186-191. 3 Ritchie, Journ. Path. and Bact. vol. xiv, 1910, p. 615. Sayce, Aust. Med. 7th, 19j7, p. 67. is R. T. Hewlett, Manual of Bact., 1908.

\section{THE EFFECTS OF EMETINE ON ABSCESS} OF THE LIVER.

By R. I. SPITTEL, F.R.C.S.Exig., gienerat hospital, colombo.

I REPORT the following case in evidence of the effects of emetine injections on amoebie abscess of the liver; also because in the near future post-mortem examinations of cases of amoebic abscess of the liver are perhaps likely to be of greater rarity than herctofore.

IIistory.-The patient, a male Cingalese labourer, aged 20, was admitted into the General Hospital, Colombo, on February 7th, 1913, complaining of fever, cough, and a swelling in the epigastric region. He had had parangi at the age of 7 , and epigastric region. He had hor at the age of 17 . For the three months previous to the date of admission he had fever which he ascribed to the date of admission he had fever which he ascribed to this being a liver abscess.

State on Admission.--He was exceedingly weak and emaciated, and complained of a chilliness and feverishness towards evening, accompanied by sweating, and of a sense of discomfort after food. There rvas a prominent swelling in the epigastrium suggesting a sense of fluctuation. The spleen was not palpable. suggesting a sense of tluctuation. The spleen was not palpable.
Over the heart there was a haemic murmur; the lungs were Over the heart there was a haemic murmur; the lungs were
clear. The general lencocrte count was 16,720 . His evening clear. The general lencocyte count was 16,720 . His evening
temperature was 99.2 .

Operation.--Emetine hydrochloride $\frac{1}{2}$ grain was given subcutaneously on February 11th, and the following day an exploring needle was plunged deeply into the epigastric prominence. As is not infrequent in these cases, no pus appeared in the syringe, but on its withdrawal, after repeated suctions, a yellow bead was noticed in the cannula. An incision was then made through the right rectus muscle, and the liver was found made through the right rectus muscle, and the liver was found peritoneal cavity having been packed off with gauze, the liver was incised, and 1! pints of grumous bile-tinged pus were evacuated. Digital exploration disclosed a large loculated cavity, the walls of which, in certain directions. were quite beyour reach of the examinin sterile water. A double drainage tube was inserted so as to fit tightly the margins of the liver incision, and gauze was care fully packed around it.

Progress.--Some foul discharge subsequently escaped, and was copious at first, but later diminished considerably in amount under treatment with $\frac{1}{2}$-grain doses of emetine dail for four days. The abscess cavity was also irrigated daily with jodine lotion (tinct. iodi $3 j$, sterile normal saline $\mathrm{Oj}$ ), and $4 \mathrm{oz}$ of quinine bi-hydrochloride solution ( $\mathrm{gr} . \mathrm{x}$ ad $\xi_{\mathrm{j}}$ ) was kept in on two accasions.

The patient made good progress nutil February 18th-six days after operation-when, in my absence, the drainage tubes were inadvertently removed and reinserted. This interfered with the newly-formed adhesions between the liver and the anterior wall of the abdomen, allowing pus to escape into the general abdominal cavity. From this time the patient's health declined; his pulse became feeble and irregular; persistent vomiting and violent diarrhoes supervened; the discharge became foul and ochry yellow in colour from the presence of became foul and ochry yellow in colour from the presence of
bile, and he died on February 21 st-or about nine days after the

bile, and he

Necropsy.-A loculated abscess cavity was found occupying the anterior aspect of the right lobe of the liver, of capacity of about $4 \mathrm{oz}$.; only $\frac{1}{4} \mathrm{in}$. thickness of liver tissue lay between the abscess and the visceral surface of the liver. A deep recess was found leading into a saccule in the immediate vicinity of the gall blalder near the neck of which the tissues had been worn down to the thinness of parchment, and had had been worn down to the thinness of parchment, and had
tapped the beginnings of the hepatic ducts. The walls of the abscess and its contents were deeply bile-stained. Pyogenic membrane merged into normal liver substance through thickness of sin. Microscopic examination of this part showed the rapid transition from inflammatory cells to fibrous tissue enveloping here and there single liver cells and groups of them. There were also several buff-coloured islets of pus organized into coherence and solidity; microscopically these areas showed inflammatory cells packed together, with filmy, fibrous strands between individual and groups. There was a consider. able quantity of pus in the general peritoneal cavity; the able quantity of pus in the general peritoneal cavity; the
mucous membrane of the colon showed a ferw scars of old ulcers.

\section{ReMarks.}

The noteworthy points of this case are:

1. The cavity in the liver, which at the time of operation contained $1 \frac{1}{2}$ pints of pus, was found nine days later to have a capacity for only $4 \mathrm{oz}$., while a very rapid advance of fibrosis was proceeding through a thickness of tissue that measured $\frac{3}{1}$ in.

2. Several separate foci of pus had been renclered inert and crystallized into solid, buff-coloured islets, which disclosed microscopically the very beginnings of fibrosis. Mere evacuations of pus and local treatment could not account for this latter phenomenon, even if they did for the former. In this connexion it may be pointed out that Rogers ${ }^{1}$ has recorded a case in which encystment of a small liver abscess occurred undcr emetine.

As for the etiology of the case, I failed to find any motile amoebae even by staining processes, but the clinical history of the case is strongly suggestive of an amoebic origin, and it has been shown by Rogers that in 98 per cent. of liver abscess in the tropics amoebic dysentery is the cause; Wenyon, ${ }^{2}$ too, has recently produced evidence to show that the Entamoeba histolytica of Schaudinn is the same as the Entamoeba tetragena of Viereck, or rather that Viereck's is the true life-history of the pathogenic amoeba that Schaudinn discovered and named.

It was not the liver abscess itself which caused the death of this particular patient, but the inadvertent removal of the drainage tubes which has been mentioned. No harm would have been done thereby if I had stitched the liver to the anterior abdominal wall at the time of the operation, but as I had no reason to anticipate the action in question $I$ adopted my usual practice in dealing with liver abscess. In future I should give preference to Rogers's method of dealing with liver abscesses-namely, to aspirate them, inject emetine hydrochloride ( 1 grain to $1 \mathrm{oz}$. of water) before withdrawing the cannula, sealing the puncture with collodion, and repeating the procedure on a further occasion if required. This is because the post-mortem findings of the case now recorded suggest that emetine besides having a specific action on the amoebae may also be an organizing and cicatrizing agent of some value. In Rogers's words, the abscess will be found to dry up.

\author{
1 Lancet, October 19th, 1912. 2 Jources. \\ Mcdicine, December, 1912.
}

\section{HAEMORRHAGE IN A NEWLY BORY INFANT.}

$$
\text { BY }
$$

S. D. CLIPPINGDALE, M.D.,

\section{LONDON.}

I necentur had to make for the coroner a post-mortem examination of a child 1 day old, who had died from severe haemorrhage (melaena, and haematemesis).

I found the stomach and small intestine full of blood. On washing the blood away I found the mucous membrane presented several ulcerations with bleeding points, from which the blood had come. The case seemed to me to be one of irritant poisoning, but on interrogating closely every person who had had anything to do with the child, I convinced myself that the child had had nothing but a little cold water. The midwife, however, informed me that when the child was born it was corered with a fetid "slime," which had come from the mother's passage. Not only was the child's head covered with this "slime," but some had entered the child's mouth, so much so that the mid wife had to hold the child up by its feet to enable the "slime" to drop out of the mouth, and had also to resort to artificial respiration. I came, therefore, to the conclusion that the ulceration and the haemorrhage had been the result of direct bacterial infection such as occurs in dysentery and in enteric fever. The coroner, a medical man, accepted my view, and directed the jury aceordingly.

I am no expert in these matters, but a noted bacteriologist, with whom I discussed this case, strongly urges that it should be placed on record. 